\title{
Celebratory Firing: A Journey from Marriage Procession to Funeral March
}

\author{
Shinto Devassy ${ }^{1}$, Zahid Ali Cholassery ${ }^{2}$
}

\begin{abstract}
Celebratory firing/happy firing is considered to be a symbol of power and masculinity. In India, it is culturally accepted in many parts during a wedding procession. The present article describes a case of death of a teenager who sustained gunshot injury while attending her relative's marriage and succumbed to death and describes the prevalence of such customs existing in the society and the various measures taken by the government and policy makers to prevent such acts and to protect every life which is lost to activities that bring only momentary pleasure. Keywords: Celebratory fire, Firearm, Gunshot.

Journal of Medical Academics (2020): 10.5005/jp-journals-10070-0050
\end{abstract}

\section{INTRODUCTION}

India is a country where celebrations and festivals are a major part of its rich culture, and people of this country take immense pride in conducting such occasions in their own unique and distinct ways. In the Diwali of 2019, when all were celebrating the festival with the usual lighting of lamps and crackers, one businessman from Bareilly, Uttar Pradesh, and his wife were seen firing on air which had gone viral on social media and is heard saying "Tera kya hoga Kalia" - a filmy dialogue from the famous Bollywood movie "Sholay". All the residents of the area became terrified and rushed indoors to safety, and this stunt was only done to stand out differently from the other people. ${ }^{1}$

Firearms are considered to be a sign of masculinity and a sense of chauvinistic pleasure and feeling of superiority and power. Weddings are the most common occasions of such demonstrations along with extreme spending of money on food and alcohol. And to make matters worse, those involved in these activities are usually drunk making these activities more dangerous. Ricocheting is also another factor, where the person will be firing on air but the pellets after hitting a surface will be turning back to the crowd. Other than this malfunction of a firearm which includes misfire, delayed discharge and insufficient or incomplete discharge to mechanical malfunctions such as stovepipe, hammer follow, or double feed can cause death while celebratory firing.

\section{Case Description}

It is an alleged history of 17-year-old female attending the marriage of her relative with her family in Pilibhit, Bareilly, Uttar Pradesh. She sustained a fatal firearm injury accidentally, while a guest attending a marriage fun by one who was attending marriage and randomly firing in the air with a gun on the afternoon of May 6, 2019. The deceased was taken initially to a nearby hospital where she was admitted and later to JPANTC, AlIMS, where she got admitted on May 14, 2019. The firearm used was an unlicensed 12-bore shot gun. According to a report of Uttar Pradesh, $60 \%$ of cases of celebratory firing in the 35 months duration were with local country-made weapons.

\footnotetext{
'Department of Forensic Medicine, Government Medical College, Haldwani, Uttarakhand, India

${ }^{2}$ Department of Forensic Medicine, All India Institute of Medical Sciences, New Delhi, India

Corresponding Author: Shinto Devassy, Department of Forensic Medicine, Government Medical College, Haldwani, Uttarakhand, India, Phone: +91 9742383741, e-mail: shinto.devassy@gmail.com

How to cite this article: Devassy S, Cholassery ZA. Celebratory Firing: A Journey from Marriage Procession to Funeral March. J Med Acad 2020;3(1):22-24.

Source of support: Nil

Conflict of interest: None
}

Her NCCT findings were showing central skull base fracture with right orbital plate fracture, right zygomatic arch fracture, right maxillary sinus and ethmoid sinus fracture, right alveolar ridge and hard palate fracture, and right frontotemporal fracture. She died on May 15, 2019, and could not be revived despite aggressive resuscitative efforts.

X-ray of the body was done, and during postmortem examination, a sutured wound was noted over the right side of face with sutures in situ and measuring $11.5 \mathrm{~cm}$. Brown scabbed abrasion with fallen off at places was noted over the right side of face over an area $10 \times 9 \mathrm{~cm}, 1 \mathrm{~cm}$ from midline and $4 \mathrm{~cm}$ from the tragus of right ear. Five black scabbed abrasions were noted over the right side of the neck over an area $5 \times 3 \mathrm{~cm}$ and size varying from $0.1 \times$ $0.1 \mathrm{~cm}$ to $0.2 \times 0.1 \mathrm{~cm}$ (Figs 1 and 2).

Subgaleal hematoma was noted over the occipital area measuring $20 \times 20 \mathrm{~cm}$ and over the entire right frontotemperoparietal area. Right-side temporalis muscle was contused. The various fractures were noted which were already mentioned in the NCCT findings. Twenty deformed pellets were recovered from the right temporalis muscle, right-side facial muscles, and sinuses. Subdural hemorrhage was noted over the right occipital area and contused areas over left occipital and left parietal area. Brain was edematous. The patient died due to head injury consequent to projectile firearm

(-) The Author(s). 2020 Open Access This article is distributed under the terms of the Creative Commons Attribution 4.0 International License (https://creativecommons. org/licenses/by-nc/4.0/), which permits unrestricted use, distribution, and non-commercial reproduction in any medium, provided you give appropriate credit to the original author(s) and the source, provide a link to the Creative Commons license, and indicate if changes were made. The Creative Commons Public Domain Dedication waiver (http://creativecommons.org/publicdomain/zero/1.0/) applies to the data made available in this article, unless otherwise stated. 


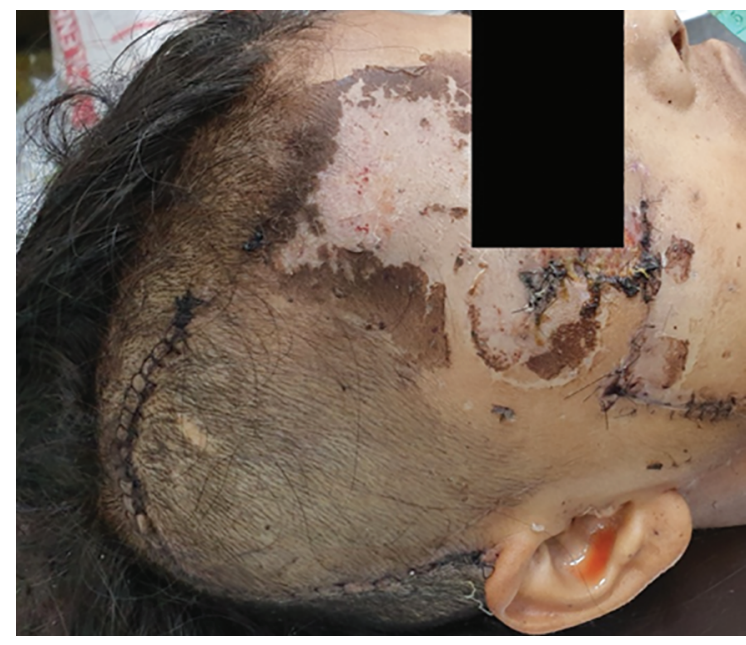

Fig. 1: Affected part of the face of the deceased

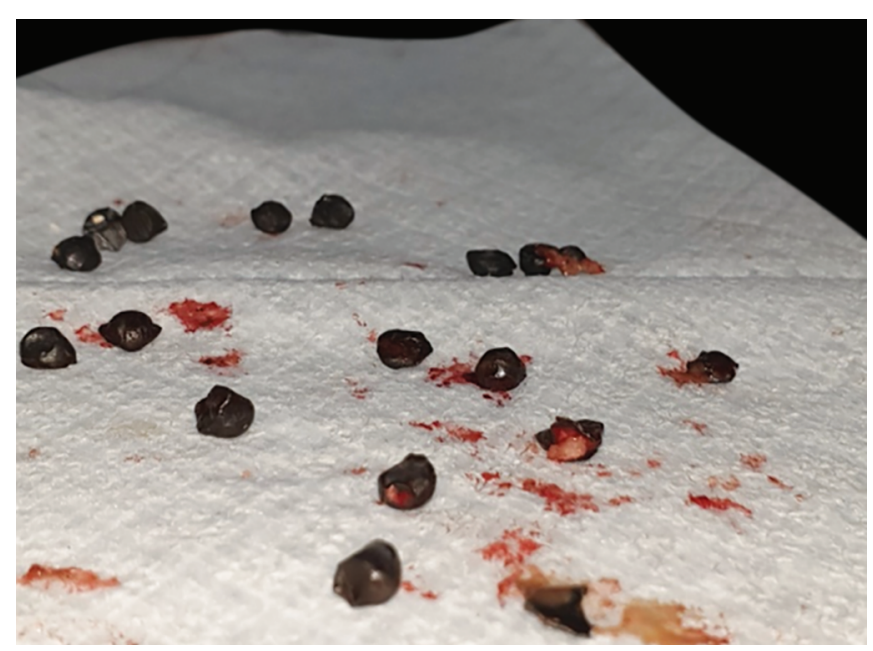

Fig. 3: Recovered deformed pellets

injury. All the pellets were handed over to the concerned police in a sealed manner (Fig. 3).

\section{Discussion}

India has about 33.69 lakh gun licences in which Uttar Pradesh tops list with a number of 12.77 lakh as on December 31, 2016. According to a recent report of National Crime Records Bureau (2017), the number of cases registered under Arms Act is 58,053. The number of firearms seized was 36,292 of which 35,873 unlicensed and 419 licensed. The maximum number of unlicensed firearms was seized from Uttar Pradesh with 20,289 and among union territories Delhi with a number of $775 .^{2}$ In the year 2016 it was 16,990 in Uttar Pradesh while 686 in Delhi. It shows the increase in the number of unlicensed firearms year by year. The accidental firearm cases reported in 2014 was 633, whereas in 2015 it was 736, and thereafter NCRB have not mentioned about the data of accidental firearm cases. ${ }^{3}$

Most of the celebratory firing cases come in the months of March, April, and July which are considered auspicious months for marriages in India. Although Uttar Pradesh and Delhi state have been banned from celebratory firing, there is no decrease in the number of cases. In a study conducted at Jawaharlal Nehru Medical College and Hospital, Aligarh, from May 1, 2007, to April 30,

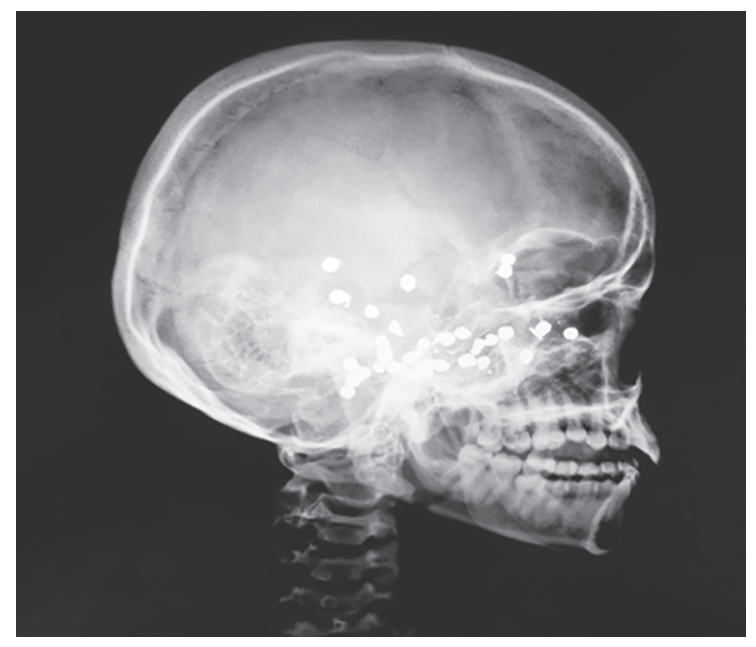

Fig. 2: X-ray face (lateral view) showing the pellets

$2008,40 \%$ of accidental firearm was due to ceremonial firing and remained as the most common cause. ${ }^{4}$

Every other day, such news is reported following celebratory firing. The father of a groom was shot dead in a happy firing during procession at Jagoti village in Ujjain district of Madhya Pradesh on November 13, 2019. ${ }^{5}$ Brother of grooms injured by celebratory firing during procession in Hapur Babugarh area of Sambhal district of on November 9, 2019. ${ }^{6}$ An Indian Army soldier died on October 31, 2019, due to celebratory firing on the day after Diwali in Meerut of Uttar Pradesh. ${ }^{7}$ RJD MLA firing from his rifle from in his terrace in Patna, Bihar, on the occasion of Diwali became viral after he only put it as a WhatsApp status. ${ }^{8}$ The investigation in celebratory firing in Delhi's Shahdara revealed that two accused are a doctor and an advocate, and both were shooting during the procession at Muskan Chowk on June 21, 2019, and the video went viral on social media following which police started investigation. ${ }^{9}$ Many more incidents would be going unreported. It is more interesting to note that most of the people involved in such activities belong to elite and educated communities, indicating that somehow this is considered as common practice and not an antisocial activity.

In the present case, the teenager lost her life too early, that too, when she had come with hopes to spend quality time with family and friends, ending so painfully and tragically. Each life is a precious, and the administration should do every effective step to protect it. The child's father itself was hiding things by saying it was a rubber bullet to save their relative at the time when X-ray was exposing the whole truth.

Delhi high court has said till the government frames guidelines on the subject, it has to fix responsibility on the organizer of the event while hearing a plea moved by the father of a teenage girl who was standing in the second floor balcony of their house watching the wedding procession and died due to the firing on the air. In September 2017, the court directed center and other agencies to frame policy in order to curb celebratory firing. Under section 336 of IPC, any act that endangers life or personal safety of others can be punished with a term which extends up to 3 months or with fine which may extend to 250 Indian rupees, or both.

The Arms Act, 1959, is related to arms and ammunition to curb the illegal weapons and violence stemming from them. Section 25 and 27 of Arms Act deals with the punishment of illegal possession 
of firearm..$^{10}$ In the Arms Rules, 2016, rule 32 deals with restriction on carrying of firearm to public places, and in such situations, the weapon should be completely covered, and he should be able to exercise effective control over the firearm. Brandishing or discharge of firearms at public places is strictly prohibited, and seizure of the weapon and in addition penalty will be imposed according to the Act. ${ }^{11}$ The Supreme Court cautioned trial courts and High Court on the case of Ayub Khan of Guna in Madhya Pradesh who was found in possession of an unlicensed country-made barrel gun. The trial court punished him with 1 year imprisonment under section 25 (1) (a) of Arms Act, whereas high court cut it down to seven days. Supreme Court ordered that Khan should undergo a minimum sentence of 3 years. ${ }^{12}$

The Arms Amendment Act, 2019, which has been passed on December 14, 2019, has mentioned about the celebratory gunfire stating that the person who use the firearms for celebratory gunfire shall be punished with 2-year imprisonment and a fine up to Rs 1 lakh which is a welcoming step. The amendment also stipulates life imprisonment for those who possessed weapons from illicit trafficking. It is the duty of the government to educate the public also an important aspect, as it has become custom in many parts of our country which can only be controlled by the strict invigilation and awareness by the local authorities.

\section{Conclusion}

Celebratory firing and death can be easily prevented by ensuring strict enforcement of law and with clear rules and regulations. It is banned in the states where it is more prevalent, and Delhi High court has mentioned that it should fix responsibility on the organizers till the central government frames rules and regulations regarding this. It is worrying that despite these efforts, the number of cases have not come down. If the local administration, police, and law enforcement agencies become more vigilant, we can save so many lives and also put an end to this ancestral display of ego, power, and pride. As the new amendment has separate provisions for controlling the celebratory gunfire, we can hope things will be changed. It is our duty to prevent a marriage procession changing to a funeral march.

\section{References}

1. Businessman UP, Wife Fire In Air on Diwali, cops investigate. (2019, October 30). Indo-Asian News Service. Retrieved November 14, 2019, from https://www.ndtv.com/india-news/bareilly-celebratoryfiring-up-businessman-wife-fire-in-air-on-diwali-cops-investigate2124613?amp=1\&akamai-rum $=$ off.

2. National Crime Records Bureau (NCRB), Ministry of Home Affairs, New Delhi. Crime in India 2017. Retrieved November 14, 2019, from, http:// ncrb.nic.in/.

3. Puri P, Shukla SK, Sarin RK, et al. Celebratory firing leads to serious injuries - a case report. Med Leg J 2019;87(1):41-44. DOI: $10.1177 / 0025817218823375$.

4. Khan I, Shakeel M, Singh P, et al. Trends in firearm injuries related to accidental causes: a study. JK Sci 2013;15:177-180.

5. Madhya Pradesh: Father of groom shot dead in pre-wedding celebratory firing. (2019, November 14).Times of India. Retrieved November 14, 2019, from https://timesofindia.indiatimes.com/city/ indore/father-of-groom-shot-dead-in-pre-wedding-celebratoryfiring/articleshow/72046136.cms.

6. Groom's brother injured in celebratory firing in Hapur. (2019, November 11). Times of India. Retrieved November 14, 2019, from https://timesofindia.indiatimes.com/city/meerut/grooms-brotherinjured-in-celebratory-firing-in-hapur/articleshow/71997635.cms.

7. Army subedar hit on head during celebratory firing in UP. (2019, October 30). Times of India. Retrieved November 14,2019, from https://timesofindia.indiatimes.com/city/meerut/army-subedar-hiton-head-during-celebratory-firing/articleshow/71810570.cms.

8. Singh $P,(2019$, October 30). RJD MLA indulges in celebratory firing, govt to cancel gun license. Republic world. Retrieved November 14,2019, from https://www.republicworld.com/india-news/generalnews/rjd-mla-indulges-in-celebratory-firing-govt-to-cancel-gunlicense.html.

9. Doctor held for celebratory firing. (2019, June 25). Times of India. Retrieved November 14, 2019, from https://timesofindia. indiatimes.com/city/delhi/doc-held-for-celebratory-firing/ articleshow/69934599.cms.

10. Indian Arms Act 1959, Govt. of India. Retrieved November 14, 2019, from https://indiacode.nic.in/bitstream/123456789/10495/1/ arms_and_ammunition_act_1959,pdf.

11. Arms rules 2016, Govt. of India. Retrieved November 14, 2019, from https://mha.gov.in/sites/default/files/FAQArmsNDAl.pdf.

12. State of MP v. Ayub Khan, (2012), 8 SCC 676 - Supreme Court of India. 